\title{
Identifikasi Sistem Drainase Untuk Penanganan Banjir Kota Medan
}

\author{
Binsar SILITONGA ${ }^{1 *}$ \\ ${ }^{1}$ Staf Pengajar Teknik Sipil Universitas Katolik Santo Thomas
}

\begin{abstract}
Medan City as the capital city of North Sumatra Province has experienced a fairly rapid development in recent years. Various development sectors grow and develop along with increasing economic growth. The housing, services and trade sector is a significant sector of progress. This has resulted in increased intensity and expansion of land use in urban areas. The cause of the flood problem in Medan City is not only absolutely in the downstream of the river, but also in the upstream and middle of the river. The more critical the water catchment area in the Deli river, which is the main watershed that flows in Medan City, where it is estimated that the good condition of the land currently only ranges from 3-4\%, causing the flow of the flow to be greater in the downstream. Thus the management and control of the flood in Medan needs to be taken into account with regard to the topographic conditions.
\end{abstract}

Kata kunci: genangan, banjir, penanganan banjir, sistem drainase

\section{Latar Belakang}

Drainase merupakan adalah salah satu unsur dari prasarana umum yang dibutuhkan masyarakat kota dalam rangka menuju kehidupan kota yang aman, nyaman, bersih, dan sehat. Prasarana drainase disini berfungsi untuk mengalirkan air permukaan ke badan air, supaya tidak ada genangan di dalam kota. Pada prinsipnya air yang masuk kedalam jaringan drainase kota diusahakan diperkecil dengan upaya pembuatan kolam didalam kota, sumur resapan bagi daerah yang air tanahnya dalam, kolam individual bagi air tanahnya yang dangkal. Selain itu juga berfungsi sebagai pengendali kebutuhan air permukaan ataupun kebutuhan pengisian air tanah guna kestabilan permukaan air tanah supaya tidak terjadi penurunan muka tanah.

Keberadaan saluran drainase sebetulnya merupakan sebagai strategi adaptasi bencana lingkungan. Curah hujan yang tinggi serta kondisi dan karakteristik wilayah seharusnya diantisipasi melalui penyediaan saluran drainase yang memadai serta terintegrasi secara keseluruhan dalam suatu sistem drainase perkotaan. Selain melalui upaya penanganan struktural tersebut, perlu juga disertai dengan penanganan non stuktural. Peningkatan kesadaran masyarakat untuk tidak membuang sampah sembarangan, peningkatan luasan bidang resapan rehabilitasi lahan kritis pada daerah hulu sungai merupakan upaya - upaya non struktural yang juga harus ditempuh guna meminimalisir kejadian banjir/genangan.

*penulis korespondensi

e-mail: binsar_silitong@yahoo.co.id 


\section{Gambaran Umum Wilayah Kota Medan}

\section{Wilayah Administratif}

Kota Medan yang memiliki luas 26.510 hektar $\left(265,10 \mathrm{~km}^{2}\right)$ mengambil prosentase 3,6\% dari keseluruhan luas wilayah Provinsi Sumatera Utara. Dengan demikian, jika dibandingkan dengan kota ataupun kabupaten lainya maka Kota Medan memiliki luas wilayah yang relatif kecil.

Secara geografis kota Medan terletak pada $3^{\circ} 30^{\prime}-3^{\circ} 43^{\prime}$ Lintang Utara dan $98^{\circ} 35^{\prime}-98^{\circ} 44^{\prime}$ Bujur Timur. Secara administratif, batas wilayah Medan adalah sebagai berikut: di Utara berbatasan dengan Selat Malaka, di Selatan berbatasan dengan Kabupaten Deli Serdang di Barat berbatasan dengan Kabupaten Deli Serdang dan di Timur berbatasan dengan Kabupaten Deli Serdang.

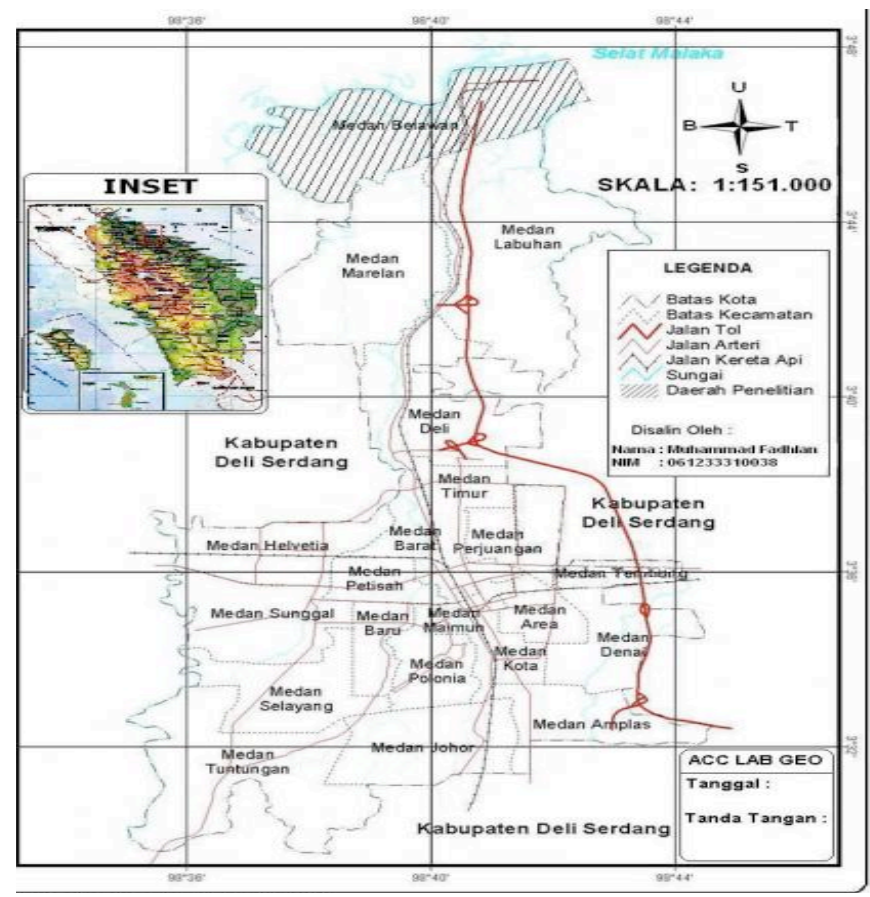

Gambar 1 Peta Administrasi Kota Medan

\section{Sebaran Penduduk Dan Peruntukan Lahan Kota Medan}

Penyebaran penduduk Kota Medan saat ini tidak merata, terkonsentrasi di kawasan pusat kota seperti di Kecamatan Medan Kota, Kecamatan Medan Perjuangan, Kecamatan Medan Maimun, Kecamatan Medan Area dan Kecamatan Medan Tembung. Sejalan dengan kecendungan perkembangan fisik kota, saat ini perkembangan pemukiman mulai mengarah ke Selatan. Perkembangan pemukiman ke arah Selatan perlu dibatasi mengingat kawasan ini merupakan daerah konservasi. Untuk itu pada masa yang akan datang perkembangan pemukiman diharapkan akan mengarah ke Utara, seperti Kecamatan medan Marelan dan Kecamatan Medan Labuhan.

Untuk lebih jelasnya, arahan pengembangan distribusi penduduk Kota Medan sampai akhir tahun 2030 yang dirinci perkecamatan dapat dilihat pada Tabel 1 seperti berikut: 
Tabel 1 Sebaran Penduduk Kota Medan Tahun 2030

\begin{tabular}{|c|c|c|c|c|c|}
\hline \multirow{2}{*}{ No } & \multirow{2}{*}{ Wilayah Kecamatan } & \multirow{2}{*}{ Luas (Ha) } & \multicolumn{3}{|c|}{ Kepadatan Penduduk (Jiwa/Ha) } \\
\hline & & & 2007 & 2018 & 2028 \\
\hline 1 & Medan Tuntungan & 2068 & 33 & 36 & 39 \\
\hline 2 & Medan Johor & 1458 & 78 & 96 & 116 \\
\hline 3 & Medan Amplas & 1119 & 101 & 158 & 238 \\
\hline 4 & Medan Denai & 905 & 152 & 180 & 209 \\
\hline 5 & Medan Area & 552 & 194 & 186 & 180 \\
\hline 6 & Medan Kota & 527 & 157 & 151 & 146 \\
\hline 7 & Medan Maimun & 298 & 191 & 255 & 333 \\
\hline 8 & Medan Polonia & 901 & 58 & 73 & 90 \\
\hline 9 & Medan Baru & 584 & 74 & 74 & 75 \\
\hline 10 & Medan Selayang & 1281 & 66 & 76 & 87 \\
\hline 11 & Medan Sunggal & 1544 & 70 & 77 & 83 \\
\hline 12 & Medan Helvetia & 1316 & 108 & 132 & 159 \\
\hline 13 & Medan Petisah & 682 & 98 & 91 & 85 \\
\hline 14 & Medan Barat & 533 & 146 & 122 & 104 \\
\hline 15 & Medan Timur & 776 & 144 & 142 & 140 \\
\hline 16 & Medan Perjuangan & 409 & 254 & 284 & 314 \\
\hline 17 & Medan Tembung & 799 & 174 & 187 & 199 \\
\hline 18 & Medan Deli & 2084 & 71 & 89 & 110 \\
\hline 19 & Medan Labuhan & 3667 & 29 & 39 & 51 \\
\hline 20 & Medan Marelan & 2382 & 52 & 97 & 171 \\
\hline 21 & Medan Belawan & 2625 & 36 & 38 & 41 \\
\hline Jumlah & 26510 & 79 & 93 & 113 & \\
\hline
\end{tabular}

Sumber : Pemko Medan

Berdasarkan rencana peruntukan lahan di Kota Medan sebagaimana arahan yang ditetapkan dalam Struktur Tata Ruang Kota Medan tahun 2005 yang dibagi dalam lima bagian Wilayah Pengembangan dan Pembangunan (WPP). Penggunaan utama lahan pada setiap WPP (WPP A s/d WPP E) diperlihatkan pada Tabel 2 seperti berikut:

Tabel 2 Pembagian Wilayah Pengembangan Dan Pembangunan (WPP)

\begin{tabular}{|c|l|l|l|}
\hline WPP & Kecamatan & $\begin{array}{l}\text { Luas } \\
(\mathrm{Ha})\end{array}$ & Peruntukan Lahan \\
\hline A & $\begin{array}{l}\text { Medan } \\
\text { Belawan }\end{array}$ & $2.625,01$ & Pelabuhan, Industri, Terminal Barang \\
\hline B & Medan Deli & $2.0384,33$ & Perumahan, Perdagangan, Perkebunan \\
\hline C & Medan Amplas & $1.118,57$ & $\begin{array}{l}\text { Perumahan, Industri Terbatas (KIM), Terminal, } \\
\text { Pergudangan, berorientasi ke konsumen }\end{array}$ \\
\hline D & Medan Johor & $1.457,47$ & $\begin{array}{l}\text { Pusat Bisnis, Pusat Pemerintahan, Perumahan, Hutan Kota } \\
\text { dan Pusat Pendidikan }\end{array}$ \\
\hline E & Medan Barat & 681,72 & $\begin{array}{l}\text { Perumahan, Perkantoran, Konservasi, Lapangan Golf dan } \\
\text { Hutan Kota. }\end{array}$ \\
\hline
\end{tabular}




\section{Topografi}

Kondisi topografi wilayah studi secara umum adalah landai dari arah Selatan ke Utara dengan kemiringan sekitar 2\%. Elevasi Kota Medan adalah bervariasi dari $+0 \mathrm{~m}$ di Utara sampai $+70 \mathrm{~m}$ di Selatan. Dari luas wilayah Kota Medan dapat dipersentasekan sebagai berikut:
a. Pemukiman $36,3 \%$
b. Perkebunan $3,1 \%$
c. Lahan Jasa $1,9 \%$
d. Sawah $6,1 \%$
e. Perusahaan $4,2 \%$
f. Kebun Campuran $45,4 \%$
g. Industri $1,5 \%$
h. Hutan Rawa 1,8\%

\section{Keadaan Iklim}

Keadaan iklim di Kota Medan sangat dipengaruhi oleh angin musim yang bertiup dengan kecepatan rendah sampai sedang di atas kepulauan Indonesia, yang datang dari arah barat laut dan barat daya, dan biasanya akan dimulai pada bulan Nopember sampai dengan bulan Mei.

Seperti umumnya seluruh wilayah Indonesia yang terletak di daerah tropis, maka keadaan iklim Kota Medan sangat dipengaruhi oleh angin musim. Ini berarti keadaan iklimnya akan ditandai dengan keadaan suhu yang relatif tinggi, kembaban udara tinggi dan disertai dengan banyak hujan. Disamping itu, karena pengaruh dari benua Asia dan Australia, maka iklimnya akan menjadi khas, yaitu dengan musim hujan dan musim kemarau. Musim hujan dimulai pada bulan Oktober atau Nopember dan berakhir pada bulan April atau Mei di tahun-tahun normal dan kurang lebih 75\% dari hujan tahunan akan jatuh dalam periode-periode tersebut.

Data iklim yang didapat dari stasiun Belawan adalah seperti berikut:

a. Suhu Udara

Suhu udara rerata tehunan, berdasarkan pengamatan yang tercatat di stasiun Belawan adalah berkisar antara $26.12^{\circ} \mathrm{C}-27.76^{\circ} \mathrm{C}$ dan suhu rerata bulanan bervariasi tiap bulannya dengan fluktuasi seperti terlihat pada Tabel 3 seperti berikut :

Tabel 3 Suhu Rerata Bulanan

\begin{tabular}{|l|l|l|l|l|l|l|l|l|l|l|l|}
\hline Bulan & Jan & Feb & Mar & April & Mei & Juni & Juli & Agust & Sept & Okt & Nop \\
\hline$\left({ }^{\circ} \mathrm{C}\right)$ & 2 & 26.8 & 27.8 & 27.37 & 27.69 & 27.76 & 27.46 & 27.07 & 26.83 & 26.49 & 26.54 \\
\hline
\end{tabular}

b. Kelembaban Udara

Kelembaban udara relatif tahunan rerata yang tercatat adalah sebesar $85.2 \%$, distribusi rerata kelembaban udara bulanannya seperti disajikan pada Tabel 4 seperti berikut:

Tabel 4 Kelembaban Rerata Bulanan

\begin{tabular}{|l|l|l|l|l|l|l|l|l|l|l|l|l|}
\hline Bulan & Jan & Feb & Mar & April & Mei & Juni & Juli & Agust & Sept & Okt & Nop & Des \\
\hline $\mathbf{( \% )}$ & 87 & 85.1 & 84.9 & 85.2 & 85.5 & 85 & 85 & 86 & 86.6 & 87.4 & 87.6 & 88.2 \\
\hline
\end{tabular}


c. Penyinaran Matahari

Rerata penyinaran matahari untuk setiap bulannya disajikan pada Tabel 5 seperti berikut:

Tabel 5 Penyinaran Rerata Bulanan

\begin{tabular}{|l|l|l|l|l|l|l|l|l|l|l|l|l|}
\hline Bulan & Jan & Feb & Mar & April & Mei & Juni & Juli & Agust & Sept & Okt & Nop & Des \\
\hline$(\%)$ & 49.7 & 66.2 & 63.3 & 61.2 & 61.2 & 62.1 & 60.9 & 59.9 & 50.3 & 44.4 & 49.9 & 43.8 \\
\hline
\end{tabular}

\section{d. Kecepatan Angin}

Rerata kecepatan angin tiap tahunnya adalah sebesar $1.65 \mathrm{~m} /$ det. Tabel 6 dibawah ini menyajikan rerata kecepatan angin harian setiap bulan yang diukur pada ketinggian 2 meter diatas permukaan tanah.

Tabel 6 Kecepatan Angin Rerata Bulanan

\begin{tabular}{|l|l|l|l|l|l|l|l|l|l|l|l|l|}
\hline Bulan & Jan & Feb & Mar & April & Mei & Juni & Juli & Agust & Sept & Okt & Nop & Des \\
\hline $\mathrm{m} / \mathrm{dt}$ & 1.47 & 1.8 & 1.71 & 1.65 & 1.23 & 1.3 & 1.4 & 1.59 & 1.22 & 1.28 & 1.53 & 1.13 \\
\hline
\end{tabular}

\section{Curah Hujan}

Data curah hujan dikumpulkan guna mengetahui besar curah hujan serta distribusi curah hujan tersebut. Data curah hujan dikumpulkan di BMG. Data curah hujan yang digunakan berasal dari 5 Stasiun Hujan berikut ini :
a. Stasiun Belawan (tahun $2000 \mathrm{~s} / \mathrm{d} 2009$ )
b. Stasiun Pancur Batu (tahun 2000 s/d 2009)
c. Stasiun Medan I (tahun $2000 \mathrm{~s} / \mathrm{d} 2009$ )
d. Polonia (tahun $2000 \mathrm{~s} / \mathrm{d} 2009$ )
e. Sampali (tahun $2000 \mathrm{~s} / \mathrm{d} 2009$ )

Untuk keperluan perhitungan Curah Hujan Rencana, data yang diperlukan adalah data Curah Hujan Maksimum Tahunan. Data Curah Hujan disajikan pada tabel berikut ini :

Tabel 7 Data Hujan Harian Maksimum berdasarkan Stasiun Belawan

\begin{tabular}{|l|l|r|}
\hline No & Tahun & Curah Hujan Harian Maksimum (mm) \\
\hline 1 & 2000 & 85 \\
\hline 2 & 2001 & 135 \\
\hline 3 & 2002 & 47 \\
\hline 4 & 2003 & 140 \\
\hline 5 & 2004 & 91 \\
\hline 6 & 2005 & 143 \\
\hline 7 & 2006 & 96 \\
\hline 8 & 2007 & 103 \\
\hline 9 & 2008 & 190 \\
\hline 10 & 2009 & 96 \\
\hline
\end{tabular}

Tabel 8 Data Hujan Harian Maksimum berdasarkan Stasiun Medan 1

\begin{tabular}{|l|l|r|}
\hline No & Tahun & Curah Hujan Harian Maksimum \\
\hline 1 & 2000 & 138.3 \\
\hline 2 & 2001 & 170.8 \\
\hline 3 & 2002 & 74.6 \\
\hline
\end{tabular}




\begin{tabular}{|l|l|r|}
\hline No & Tahun & Curah Hujan Harian Maksimum \\
\hline 4 & 2003 & 97.6 \\
\hline 5 & 2004 & 100.2 \\
\hline 6 & 2005 & 87.9 \\
\hline 7 & 2006 & 124.8 \\
\hline 8 & 2007 & 88.2 \\
\hline 9 & 2008 & 82.4 \\
\hline 10 & 2009 & 115.4 \\
\hline
\end{tabular}

Tabel 9 Data Hujan Harian Maksimum berdasarkan Stasiun Pancur Batu

\begin{tabular}{|l|l|r|}
\hline No & Tahun & Curah Hujan Harian Maksimum (mm) \\
\hline 1 & 2000 & 106.5 \\
\hline 2 & 2001 & 145 \\
\hline 3 & 2002 & 99 \\
\hline 4 & 2003 & 118 \\
\hline 5 & 2004 & 76 \\
\hline 6 & 2005 & 190 \\
\hline 7 & 2006 & 159 \\
\hline 8 & 2007 & 219 \\
\hline 9 & 2008 & 83 \\
\hline 10 & 2009 & 87 \\
\hline
\end{tabular}

Tabel 10 Data Hujan Harian Maksimum berdasarkan Stasiun Polonia

\begin{tabular}{|l|l|r|}
\hline No & Tahun & Curah Hujan Harian Maksimum $(\mathrm{mm})$ \\
\hline 1 & 2000 & 138.3 \\
\hline 2 & 2001 & 164.7 \\
\hline 3 & 2002 & 74.6 \\
\hline 4 & 2003 & 97.6 \\
\hline 5 & 2004 & 100.2 \\
\hline 6 & 2005 & 124.8 \\
\hline 7 & 2006 & 88.2 \\
\hline 8 & 2007 & 88.4 \\
\hline 9 & 2008 & 115.2 \\
\hline 10 & 2009 & 72.4 \\
\hline
\end{tabular}

Tabel 11 Data Hujan Harian Maksimum berdasarkan Stasiun Sampali

\begin{tabular}{|l|l|r|}
\hline No & Tahun & Curah Hujan Harian Maksimum (mm) \\
\hline 1 & 2000 & 79.3 \\
\hline 2 & 2001 & 165.6 \\
\hline 3 & 2002 & 98.6 \\
\hline 4 & 2003 & 150.5 \\
\hline 5 & 2004 & 122.8 \\
\hline 6 & 2005 & 116 \\
\hline 7 & 2006 & 111.8 \\
\hline
\end{tabular}




\begin{tabular}{|l|l|r|}
\hline No & Tahun & Curah Hujan Harian Maksimum $(\mathrm{mm})$ \\
\hline 8 & 2007 & 134.5 \\
\hline 9 & 2008 & 90 \\
\hline 10 & 2009 & 102.5 \\
\hline
\end{tabular}

Sumber : $B M K G 2010$

\section{Permasalahan Drainase Kota Medan}

Permasalahan drainase di Kota Medan secara umum dapat diuraikan sebagai berikut:

a. Sebagian besar genangan yang tercatat di lokasi produktif.

b. Elevasi sungai Deli lebih tinggi dari daerah lainnya.

c. Over Load debit Saluran Sulang Saling.

d. Saluran Sei Putih, Sei Bamban, Sei Batuan, dan Sei Badra masih di dominasi dengan saluran alami.

e. Tidak ada aturan standar baku tentang saluran tertutup.

f. Flood Way tidak dapat terlalu membantu masalah over debit drainase Kota Medan secara langsung.

g. Tidak ada saluran drainase yang melintas pada rel kereta yang membujur dari Selatan ke Utara di Kota Medan.

h. Belawan mengalami genangan akibat ROB.

\section{Sistem Drainase Makro Kota Medan}

Sistem drainase makro Kota Medan memiliki 3 sistem yaitu :

a. Sistem Sungai Sunggal,dengan Drainase Makronya Sungai Sunggal

b. Sistem Sungai Deli, dengan Drainase Makronya Sungai Deli dan Sungai Barbura

c. Sistem Sungai Percut, dengan Drainase Makronya Sungai Percut

Adapun kondisi drainase makro yang ada saat ini dapat dijelaskan sebagai berikut ini.

- Sistem Sungai Sunggal

- Sungai utama adalah Sungai Sunggal dengan lebar sekitar 25 m dan kedalaman sekitar $5 \mathrm{~m}$

- Merupakan sungai alam yang belum dilakukan penanganan

- Sungai ini berapa kali mengalami banjir walaupun jarang. Dan pada tahun 2011 mengalami banjir dengan area terdampak cukup luas.

- Sungai Deli

- Sungai utama adalah Sungai Deli yang memiliki lebar 20 - 45 meter serta kedalaman sungai 2,5 - 7,0 meter.

- Telah pernah dilakukan penanganan untuk Sungai Deli yaitu dengan pembuatan Flood Way yang dialiarkan ke Sungai Percut. Akan tetapi masih sering terjadi banjir pada daerah sekitar sungai tersebut.

- Sungai Percut

- Sungai utama adalah Sungai Percut

- Sungai ini telah dilakukan normalisasi sehubungan dengan pembuaatan flood way pada Sungai Deli.

- Tidak pernah mengalami banjir.

\section{Sistem Drainase Mikro Kota Medan}

Yang disebut drainase mikro adalah drainase yang daerah tangkapan (cathment area) nya masih didalam kota Medan. Sistem drainase mikro Kota Medan dibagi menjadi beberapa 
drainage area (DA) untuk memudahkan dalam penangannya. Adapun DA yang dimaksud adalah:

a. Sistem Sunggal

b. Sistem Bandera

c. Sistem Bamban

d. Sistem Sei Putih

e. Sistem Sungai Babura

f. Sistem Sungai Deli

g. Sistem Sungai Batuan

h. Sistem Sulang Saling

i. Sistem Percut

j. Sistem Belawan

\section{Kesimpulan dan Rekomendasi}

\section{Kesimpulan}

Dari hasil identifikasi dan paparan atas kondisi system drainase di Kota Medan, maka dapat disimpulkan seperti berikut:

1. Kota Medan memiliki topografi yang relatif landai dengan daerah rendah serta laut pada bagian hilir yang berpotensi membuat pengaliran air ke hilir lebih lambat,

2. Ada cukup banyak aliran air sungai yang melewati Kota Medan yang dapat dipakai sebagai bagian dari sistem drainase perkotaan untuk penanganan genangan ataupun banjir,

Yang dipaparkan pada tulisan ini baru memperlihatkan kondisi topografi, data iklim dan besar hujan serta sistem drainase yang ada di Kota Medan.

\section{Rekomendasi}

Direkomendasikan untuk melakukan analisa dan perhitungan kemampuan dimensi dari setiap sistem drainase yang ada untuk mengetahui kelemahan dari setiap sistem sehingga penanganan banjir ataupun genangan di Kota Medan lebih tepat.

\section{Daftar Pustaka}

Data Hujan dari BMKG Wilayah I

Sasongko, D. (1989). Teknik Sumber Daya Air Jilid I. Jakarta: Penerbit Erlangga.

Sosrodarsono, S. (1989). Hidrologi Untuk Pengairan. Bandung

Statistik, B. P. (2016). Kota Medan Dalam Angka. Medan: Anonim. 